\title{
Language Choices Used by Mixed Marriage Children
}

\author{
Ni Ketut Ayu Kertiana Dewi ${ }^{1 *}$ A. A. Sg. Shanti Sari Dewi ${ }^{2}$, I Gede Budiasa ${ }^{3}$ \\ ${ }^{[123]}$ English Department, Faculty of Arts, Udayana University \\ [1ayukartiana@gmail.com], ${ }^{2}$ [jungshanti@yahoo.com], ${ }^{3}$ [budiasigede@yahoo.com] \\ *Corresponding Author
}

\begin{abstract}
This paper is entitled Language Choices Used by Mixed Marriage Children. This study focuses on the strategies of communication applied by the parents in raising their children, the language frequently spoken by the children and the factors affecting the children in choosing a certain language. There are two children, Jasmine and George, being observed in this study. In this study the data were collected by direct interview with the parents and children, questionnaires, and observation. The conversations made by the children, Jasmine and George, with their parents, their aunty, the nanny and their private teacher were recorded. The collected data were analyzed by using qualitative method and descriptive technique applying the theory proposed by Romaine (1995) and Holmes (2001). As a result of this study, strategy 1: 'one person-one language' is successfully applied by the parents in this family in raising their bilingual children. They communicate with their own language to the children from birth. So, the children, Jasmine and George, fluently speak two languages, namely Indonesian and English. However, English is the language spoken more frequently by the children and the children in this study know with whom to talk certain languages according to the participants, settings and topics.
\end{abstract}

Key words: mixed marriage, bilingual children, strategy, domain, language choice

\begin{abstract}
Abstrak
Karya ilmiah ini berjudul Pilihan Bahasa yang Digunakan Oleh Anak-Anak dari Pernikahan Campuran (Language Choices Used by Mixed Marriage Children). Penelitian ini berfokus pada strategi komunikasi yang diterapkan oleh orang tua dalam membesarkan anak-anak mereka, bahasa yang paling sering digunakan oleh anak-anak, dan faktor-faktor yang memepengaruhi mereka dalam pemilihan bahasa tertentu. Penelitian ini melibatkan dua orang anak bernama Jasmine dan George yang diamati secara langsung. Data untuk penelitian ini diperoleh dengan cara melakukan wawancara langsung dengan orang tua dan anak-anak mereka, melakukan kuisioner dan pengamatan. Percakapan yang melibatkan Jasmine dan George dengan orang tua, bibi, pengasuh, dan guru pribadi mereka diambil dengan cara direkam. Data yang diperoleh dianalisa dengan menggunakan metoda kualitatif dan teknik deskriptif dengan menggunakan teori yang dikembangkan oleh Romaine (1995)dan Holmes (2001). Hasil penelitian ini menunjukkan bahwa strategi 1: one person-one language berhasil diterapkan oleh orang tua yang diteliti dalam penelitian ini dalam membesarkan anak-anak mereka. Orang tua mereka menggunakan bahasa mereka masing-masing dalam berkomunikasi dengan anak-anak mereka sejak lahir. Sehingga, Jasmine dan George fasih dalam berbicara dalam bahasa Inggris dan bahasa Indonesia. Akan tetapi, bahasa Inggris adalah bahasa yang paling sering digunakan oleh Jasmine dan George dan mereka tahu dengan siapa mereka menggunakan bahasa tertentu berdasarkan pada orang yang dituju, tempat dan topik
\end{abstract}

Kata kunci:pernikahan campuran, anak bilingual, strategi, domain, pilihan bahasa 


\section{Background of the Study}

Language is a means of social interaction that is defined as a symbolic system of sound produced by the utterance to interact with others in daily social life. One of the most interesting aspects of language is Sociolinguistics that studies about the relationship between language and society. Someone who engages in this study is called a sociolinguist who pays attention to why people use different varieties of language in different social contexts and it provides a lot of information about how language works.

Bilingualism is defined as the ability to use at least two languages by an individual. There are a lot of factors causing a person to become a bilingual. One of the most common factors is mixed marriage which involves two people with different languages and cultural backgrounds. Being bilingual allows us to choose which language we want to use to communicate with certain addressee. Language choice, as one of the famous phenomena in sociolinguistics, refers to the selection of languages appropriate with participants, topics and locations known as domain in language used.

Based on those phenomena, this study analyzed how the mixed marriage family manages the languages and the factor influencing the child in choosing certain language for different domain.

\section{Problem of the Study}

a) What strategies of communication are applied by the parents in raising their bilingual children?

b) Which language is spoken more by the children?

c) What factors affect the children in choosing a certain language?

\section{Aims of the Study}

a) To identify the strategies of communication applied by the parents in raising their bilingual children.

b) To identify which language is spoken more by the children.

c) To analyse the factors affecting the children in choosing a certain language.

\section{Research Method}

Methodology is a set of procedures in the systematic study applied within a discipline. The research method in this study is classified into four points, namely, choosing the relevant data source, how the data were selected, how the data were analysed, and how the data were presented.

\subsection{Data Source}

The children of mixed marriage family were chosen as the main data in this study whose father is native English speaker and mother is an Indonesian. Jasmine and George were chosen as the objects of this study because they are mixed marriage children and definitely bilingual. They speak English with their father, Indonesian and English with their mother.

\subsection{Method and Technique of Collecting Data}

The data of the children were obtained by using participatory observation, because Jasmine and George as the subject were observed directly for three months, starting from September, 2017 to November, 2017. The technique used in obtaining the data was by interviewing, answering questionnaire, and recording. 


\subsection{Method and Technique of Analysing Data \\ In this study the qualitative} method and descriptive technique were used in analysing the collected data. The collected data were further analysed based on the theory of raising children bilingually by Romaine (1995) and bilingualism by Holmes (2001).

\subsection{Method and Technique of Presenting Analysis}

Since this study used qualitative method, the data analysis was descriptively presented. It means that the findings were explained through sentences. The conversation of the child with family members and nanny named Dorkas were presented and explained using sentences.

\section{Result and Discussion}

In this chapter, there are several points discussed concerning with the strategies of communication applied by the parents in raising their children, the language that is frequently spoken by the children and the factors affecting the children in choosing a certain language.

\subsection{The strategy of communication applied by the parents in raising their bilingual children is proposed by Romaine (1995). There are six types of strategy:}

- Type 1: One Person One Language

- Type 2: Non-dominant Home Language/one Language One Environment

- Type 3: Non-dominant Home Language without community support

- Type 4: Double Non-dominant Home Language without Community Support

- Type 5: Non-native Parents

- Type 6: Mixed Languages
Based on the observation, the parents from this family introduce the languages simultaneously. They transmit both of their languages; English is the father's language and Indonesian is the mother's language, at the same time to the children, Jasmine and George, from birth.

In accordance with the theory above and by examining the collected data, strategy Type 1: 'one person-one language' is successfully adopted by the parents in raising their children bilingually. The strategy is matching for this family in the way they are raising their children. In this case, the father communicates in English and the mother communicates in Indonesian and English with their children. This strategy is chosen by the parents because it is claimed as the effective strategy in raising bilingual children.

(1-1) Dialogue 1 Conversation between jasmine and her mother

Mother : Jasmine tadi kan mommy sudah bilang cariin work sheet adik di map putih.

Jasmine : Sudah jasmine cari tadi ga ketemu.

Mother : Tadi mommy nelfon kamu bilang sudah, sudah. Tapi ini masih disini.

Jasmine : Jasmine ga tau.

Mother : Kamu udah selesai lesnya?

Jasmine : Jasmine sudah selesai tadi, itu Gio dari tadi ga belajar, dia maen aja kerjaannya.

(1-2) Dialogue 2 Conversation between George and his mother

George : Mommy jam berapa ini?

Mother : Iya sudah jam 9. Ayo Jasmine George gosok gigi dulu.

George : Sebentar lagi ya mommy? (Keep playing with his toys) 
Mother : Ga, sudah malam, gosok gigi dulu habis itu siapin buku untuk besok.

George : Ya ya.

(1-3) Dialogue 3 Conversation between Jasmine, George and the parents

Father : Jasmine, when I laid on Saturday already salju, some salju.

Jasmine : In England?

George : We are leaving on this Saturday daddy?

Father : No, when I came to Bali last Saturday.

Jasmine : Dad is there is a chance for snow in January?

Father : I hope so, yeah.

Mother : You know, in aunty Kadek house is snow. She send a picture.

Jasmine : Ha..! I wanted that snow.

Mother : Ya, the snow is on the top of aunty Kadek car. My God, how cold is this dad?

Father : It could be a little bit cold here this winter.

In dialogue 1 and dialogue 2 Indonesian was used by the mother when talking to the children and this points out their fluency in that language. In the same way, the father in dialogue 3 uses English in communicating with Jasmine and George. The mother also uses English because the conversation is commenced by the father using English.

The conversations proved that the parents of Jasmine and George are successfully applied Strategy 1: 'one person-one language' proposed by Romaine (1995). This strategy is applied by using their own language in communicating with their children, Jasmine and George. From the conversation, it can be said that the children are not only competent in Indonesian, but in English as well.

\subsection{Language Choice Made by the Children.}

This section analyses the language choice that occurs in the speech of Jasmine and George. Holmes (2001:23) states that domain is clearly a very general concept which draws important social factor in code choice and three domains mentioned in her book are participant, setting, and topic. It is certainly affecting the children in this study, Jasmine and George, in choosing a certain language when they are speaking depends on participants, situation and function of interaction.

In this case, the communication occurs in family domain, the participant involves are Jasmine, George, father, mother and the nanny and the conversations took place in their house.

(1-4) Dialogue 4 Conversation between Jasmine and her father

Jasmine: How about this dad?

Father : Sauce nice, its mean more salty, more meat,

Jasmine : I think the pasta need to be boiled more.

Father : Boiled more? You think it should be little bit hard?

Jasmine : Ya.

Father : Pasta could be called Al dente, which means firm.

Jasmine : Daddy my spaghetti is hard.

Father : It supposed to be hard. Spaghetti is not might to be soft, it is might to be $\mathrm{Al}$ dente which means firm.

(1-5) Dialogue 5 Conversation between George and his father

George : Jasmine!

Jasmine : What did I do? 
George : When I wrote, no dogs allowed to my room, no dogs allowed.

Jasmine : (laugh).

Father : Who write no dogs allowed?

George : Jasmine, she rewrote this.

Father : Are you sure?

George : yes, she did. Cannot you see her hand writing daddy?

Father : May be your mommy who wrote that or aunty Dadek wrote that. Jem you wrote that?

George : I'll try to write something dady. You see the different dad

Father : Hem, yeah.

Geroge : Of course it's Jasmine, she like using girly colors.

Dialogue 4 is between Jasmine and her father talking about spaghetti that they have for dinner, and dialogue 5 is between George and his father about notification that dog is not allowed to enter the bedroom.

This part of the conversation between Jasmine, George and their father shows that the father only used English to speak with his children and so does the children.

(1-6) Dialogue 6 Conversation between Jasmine and her mother

Mother : Ayo sudah Jasmine, sekarang yang lain topiknya Jasmine. Kata dasar yang berawalan me- cobak Jasmine.

Jasmine : Oh kata dasar yang berawalan apa?

Mother : Kata dasar yang berawalan me-

Jasmine : Memasak-masak, membacabaca, menggendongngendong.

Mother : Gendong, menggendong.

Jasmine: Hahaha gendong, menggendong.

(She laughed because she said wrongly the base of word menggendong)
Mother : Sapu, menyapu. Beri?

Jasmine : Memberi.

Mother : Nilai?

Jasmine : Menilai.

(1-7) Dialogue 7 Conversation between George and his mother

Mother : Cobak liat mommy. Sampe jalan Drupatir, terus dari Drupatir tu kemana terus?

George : Dan belok kiri.

Mother : Kemudian, jangan dan dan terus. Kemudian bisa pake, lalu boleh.

George : Kemudian belok kiri. Belok kiri jalan terus...

Mother : Ke-, belok kiri ke jalan itu, kasik ke-nak.

George : Ke jalan Arjuna. Dan belok kanan.

Mother : Belok kanan lagi? Oohh ok. Lalu, kasik lalu sekarang jangan terus dan, tadi kan sudah.

George : Lalu belok kanan.

Dialogue 6 and dialogue 7 is between Jasmine, George and their mother. The conversations took place when their mother helps them do the homework. The language used by them in communicating with each other is Indonesian.

(1-8) Dialogue 8 Conversation between Jasmine, George and the nanny

Nanny : George mau lunch apa untuk besok?

George : Mi goreng.

Nanny : Isi bacon?

George : No.

Nanny : Isi nugget?

George : Tidak.

Nanny : Terus untuk breakfast besok pagi apa?

George : Pancake.

Nanny : Jasmine mau apa besok lunchnya?

Jasmine: Nasi sama nugget. 
Nanny : Sarapannya?

Jasmine: Jasmine mau bacon, tapi jangan kering gorengnya.

Dialogue 8 is between Jasmine, George and the nanny. The topic discussed is about breakfast and lunch. In the conversation Jasmine and George used Indonesian in speaking with the nanny.

From all the data, it was found that the language choice made by Jasmine and George are English and Indonesian. They mixed the languages but English is the language spoken more by the children. Both of them are knowledgeable of the possibility of making choice in using language depending on with who they are talking to, when and where they are talking, and what are they talking about.

\subsection{Factors Affecting the Children in Choosing Language.}

Romaine (1995) mentions that there are two factors affecting the child's bilingualism, namely personal and attitude factors. Personal factors might concern all those that have to do with the children themselves, including their feelings about being bilinguals or whether they have a natural talent in developing the languages. The attitudinal factor is divided into the attitude of the family and attitude of teacher.

\section{(1-9) Personal Factors}

The ability of George in Indonesian is quite different from Jasmine. George chooses low level class in Indonesian Language subject because he is not confident in his ability of Indonesian. On the other side, Jasmine is confident in using Indonesian and it can be said that she is mastering both languages.

Some may have no issue in learning another language and others may face difficulties, every child has different abilities in learning language.

\section{(1-10) Attitude of the family}

From the findings, both parents have the same opinion and supported each other in raising their children bilingually. They concern about the importance of their children to be equally fluent in English and Indonesian. As mentioned previously the parents, Mr. Robbert and Mrs. Siska, come from different languages and cultural backgrounds and decided to raise their children bilingually. They intentionally raised their children by using strategy Type 1: one person-one language where the parents each transmit their own language when speaking to the children.

\section{(1-11) Attitude of teacher}

The people who are close to the children, Jasmine and George, are their teachers at school and their private teacher at home, who also for this reason are included as one of the factors influencing the children's bilingualism. Jasmine and George also learn both languages English and Indonesian at school. English is used as a means of instruction and Indonesian is used when they are in Indonesian Language class. The circumstance also plays an important role in affecting the children in choosing the language.

\section{Conclusion}

This study analyzed two children, Jasmine and George, from mixed marriage family between British husband, Nigel Robert Easton, and Indonesian wife, Putu Siska Aprilyna.

The strategy used by this family in raising their children bilingually is Strategy 1: One person-one language proposed by Romaine (1995). This strategy has characteristics where both 
parents use their own language when talking to the children and one of the parents' languages is the dominant language of the community. In this case, Mr. Robert always speaks English with his children and Mrs. Siska speaks Indonesian with her children and so do the children.

The findings also show that the children from this mixed marriage family speak two different languages, English and Indonesian. They could place themselves and use certain languages, depending on with whom they are talking to, the topic and the situation when they do the conversation. This study also reveals that the language spoken more by the children is English. Even if they mix the languages, English is dominantly used. This situation is influenced by the attitude of the parents, teachers and friends and the most factor affecting it is personal factor which comes from the children themselves.

\section{Bibliography}

Bloomfield, L. (1933). Language. Holt, Rinehart \& Wiston, New York.

Bossard, J. H. S and Boll, E. S. (1957). One Marriage, Two Faith: Guidance on Interfaith Marriage. Ronald Press Co,

Bruce, E. G. (2008). Cognitive Psychology: Connecting Mind, Research, and Everyday Experience, second edition. Thomson.

Fishman, J. A. (1972). The Description of Social Bilingualism. Stanford University Press, California.

Grosjean, F. (1982). Live with Two Languages: An Introduction to Bilingualism. Mass: Harvard University Press, Cambridge.
Hamers, J.F \& Blanc, H.A. (2004). Bilinguality and bilingualism, second edition. New York, NY: Cambridge University Press.

Holmes, Janet. (2001). An Introduction to Sociolinguistics, second edition. Person Education Limited, England.

Romaine. (1995). Bilingualism, second edition. Blackwell: USA.

Wardhaugh, R. (1986). An Introduction to Sociolinguistics. Basil Blackwell Ltd, New York. 